\title{
PERBEDAAN PENDAPATAN USAHA BUDIDAYA IKAN BANDENG (Chanos chanos) INTENSIF DAN NON INTENSIF DI KECAMATAN MANYAK PAYED KABUPATEN ACEH TAMIANG
}

\author{
Siti Balqies Indra ${ }^{1} / J$ ko Susilo ${ }^{2}$ \\ ${ }^{1}$ Dosen Tetap Prodi Agribinis \\ ${ }^{2}$ Alumni Prodi Agribinisnis \\ Fakultas Pertanian Universitas Samudra
}

\section{RINGKASAN}

Tujuan penelitian untuk menganalisis perbedaan pendapatan usaha budidaya ikan bandeng (Chanos chanos) di Kecamatan Manyak Payed Kabupaten Aceh Tamiang. Di bawah bimbingan Muhammad Jamil dan Siti Balqies Indra.

Penelitian ini dilaksanakan di Kecamatan Mayak Payed Kabupaten Aceh Tamiang. Penentuan lokasi penelitian dilakukan dengan sengaja (purposive), dengan pertimbangan bahwa di Kecamatan Manyak Payed Kabupaten Aceh Tamiang terdapat usaha budidaya ikan bandeng secara intensif dan non intensif. Penelitian menggunakan metode survey. Objek penelitian ini adalah pengusaha tambak usaha budidaya ikan bandeng secara intensif dan non intensif di Kecamatan Manyak Payed. Ruang lingkup penelitian ini hanya mengkaji pendapatan pengusaha usaha budidaya ikan bandeng secara intensif dan non intensif. Penelitian dilaksanakan pada bulan Februari 2016 sampai bulan Maret 2016. pengusaha budidaya ikan bandeng intensif sebanyak 21 orang semuannya dijadikan sampel penelitian. Sedangan pengusaha budidaya ikan bandeng non intensif populasinya sebanyak 502 orang sebanyak 30 orang dijadikan sampel penelitian.

Rata-rata pengunaan tenaga kerja usaha budidaya ikan bandeng non intensif yaitu sebesar 34,07 HKP/Periode dengan rincian 21,07 HKP/Periode dan intensif yaitu sebesar 85,25 HKP/UT/Periode. Rata-rata biaya produksi usaha budidaya ikan bandeng non intensif di Kecamatan Manyak Payed yaitu sebesar Rp. 3.879.017,86,- perUT/Periode dan intensif yaitu sebesar Rp. 7.536.591,53- perUT/Periode.

Rata-rata produksi ikan bandeng usaha budidaya non intensif sebesar 484,42 Kg/UT/Periode dan 351,66 Kg/Ha/Periode dan intensif yaitu sebesar 728,19 $\mathrm{Kg} / \mathrm{UT} /$ Periode dan 521,91 $\mathrm{Kg} / \mathrm{Ha} /$ Periode. Rata-rata nilai produksi usaha budidaya ikan bandeng non intensif di Kecamatan Manyak Payed yaitu sebesar Rp. 9.688.333,33,- /Usaha/Periode dan Rp. 7.033.272,84,-/Ha/Periode dan intensif yaitu sebesar Rp. 16.020.190,48,-/Usaha dan Rp. 11.482.047,78,-/Ha/Periode. Rata-rata pendapatan bersih usaha budidaya ikan bandeng non intensif di Kecamatan Manyak Payed yaitu sebesar Rp. 5.809.315,48 perUT/Periode dan Rp. 4.338.971,21 per Ha/Periode dan intensif yaitu sebesar Rp. 8.483.598,94- per UT/Periode dan Rp. 6.042.300,43,- per Ha/Periode.

Dari hasil perhitungan tersebut diperoleh $t_{\text {cari }}=13,101$ sedangkan $t_{\text {tabel }}$ pada tingkat keyakinan $95 \%(\alpha=0.05)$ sebesar 1,665 dan pada tingkat keyakinan $99 \%(\alpha=0.01)$ sebesar 2,405 . Ini berarti $t_{\text {cari }}>t_{\text {tabel }}$ baik pada tingkat keyakinan 95\% maupun 99\%. Dengan demikian dapat disimpulkan terima Ha dan tolak Ho. Artinya ada perbedaan yang sangat nyata antara pendapatan bersih usaha budidaya ikan bandeng non intensif dan intensif.

Kata Kunci: Budidaya, Bandeng, Intensif, Non Intensif, Pendapatan, Perbedaan

\section{PENDAHULUAN \\ Latar Belakang}

Indonesia adalah salah satu negara agraris yang sebagian besar penduduknya tinggal di pedesaan dan menggantungkan hidupnya pada sektor pertanian. Sebagai negara berkembang sector pertanian masih memegang peranan penting dari keseluruhan nasional, hal ini dapat ditunjukkan dari banyaknya penduduk atau tenaga kerja yang hidup atau bekerja pada sektor pertanian.
Pembangunan pertanian dititik beratkan pada pembangunan pertanian tangguh, berbudaya industri dan berwawasan agribisnis. Sebagai salah satu sector pemberi konstruksi terutama sebagai pemasok bahan baku bagi industri akan membuka peluang terciptanya lapangan kerja bagi masyarakat sehingga lapangan kerja dapat terserap dan mengurangi angka pengangguran. Sektor perikanan juga merupakan sektor dalam penyumbang devisa negara, pengembangan perikanan secara nasional dan terpadu 
khususnya komoditas perikanan komersial yang mencakup ikan dan non ikan dalam rangka peningkatan ekspor hasil perikanan.

Pengembangan budidaya tambak di daerah pesisir pantai perlu memperhatikan daya dukung lahan, pengembangan tambak yang melampaui daya dukung lingkungan (produktivitas) akan menimbulkan berbagai dampak seperti krisis $\mathrm{pH}$ tanah, kualitas $\mathrm{pH}$ air, kehidupan mikro oraganisme yang semakin berkurang dan sulit diatasi. Daya dukung lahan pesisir untuk pertambakan ditentukan oleh kualitas sumber air asin (asin dan tawar), arus pasang surut (hidrooseanografi) tofografi dan klimatologi daerah pesisir dan daerah aliran sungai di daerah hulu.

Salah satu jenis ikan yang dibudidayakan di tambak ialah ikan bandeng (Chanos chanos). Budidaya ikan bandeng telah lama dikenal oleh petani dan saat ini telah berkembang dihampir seluruh wilayah perairan Indonesia dengan memanfaatkan perairan payau dan pasang surut. Teknologi budidaya ikan ini juga telah mengalami perkembangan yang begitu pesat mulai dari pemeliharaan tradisional yang hanya mengandalkan pasok benih dari alam pada saat pasang, sampai ke teknologi intensif yang membutuhkan penyediaan benih, pengelolaan air dan pakan secara terencana. Ikan ini sangat digemari oleh masyarakat Indonesia dan banyak sekali disajikan di warung-warung makan untuk konsumsi masyarakat yang berpengahsilan menengah ke bawah.

Bandeng banyak mengandung mineral, vitamin dan asam lemak omega 3 yang sangat dibutuhkan oleh kesehatan, sama halnya dengan salmon atau jenis ikan lainnya. Ikan bandeng juga dipercaya bisa meningkatkan kesehatan, bahkan kecerdasan otak anak. Ikan yang disebut juga "Milkfish" ini disukai karena tidak terlalu manis, lezat, tidak asin seperti ikan lainnya dan tidak mudah rusak saat dimasak.

Harga ikan ini relatif murah, dapat terjangkau oleh semua lapisan masyarakat, sehingga dapat memberikan andil yang cukup besar dalam meningkatkan gizi masyarakat. Ikan bandeng sebagai komditas budidaya yang telah mapan untuk tingkat petani tambak, upaya efisiensi budidayanya merupakan tuntutan utama, sehingga dapat meningkatkan pendapatan para petani dan nelayan.
Menurut Ibnu (2004:2), ikan bandeng banyak digemari oleh sebagian besar masyarakat Indonesia karena rasanya yang khas, tekstur dagingnya lunak dan murah harganya sehingga dapat dijangkau oleh seluruh lapisan masyarakat. Ikan bandeng dapat diolah dalam berbagai bentuk seperti bandeng asap, pindang bandeng duri lunak dimana masing-masing produk memiliki rasa dan aroma khas yang banyak menarik minat masyarakat.

Meningkatnya konsumsi masyarakat akan bandeng menjadikan usaha budidaya ikan bandeng tahap demi tahap terus menunjukkan peningkatan. Perkembangan yang pesat dari usaha budidaya bandeng di tambak harus pula di imbangi dengan penyediaan benih (nener) secara berkesinambungan dalam jumlah yang cukup dan berkualitas prima. Hal ini dimaksudkan untuk menjamin ketersediaan bandeng sepanjang tahun pada tingkat produksi maksimal dan berkesinambungan.

$$
\text { Menurut Yusuf (2003:5), }
$$

pengembangan ikan di Aceh memiliki arti yang strategis dalam menanggulangi kemiskinan di wilayah tersebut. Jumlah penduduk miskin di Aceh sekitar 36\% dan lebih dari $80 \%$ nelayan tergolong miskin. Padahal, Aceh memiliki potensi yang cukup besar dengan panjang pantai $2.467 \mathrm{~km}$, luas areal budidaya $43.173,5$ hektar, serta potensi lestari laut sekitar 493.930 ton pertahun.

Perkembangan budidaya ikan di Aceh, terutama budidaya ikan bandeng di baik intensif maupun non intensif banyak dilakukan oleh nelayan pesisir pantai. Melihat luasnya wilayah perairan Aceh, mendorong para nelayan untuk melakukan budidaya ikan bandeng di tambak, termasuk juga masyarakat nelayan di Kecamatan Manyak Payed Kabupaten Aceh Tamiang yang juga memiliki potensi perairan yang baik untuk melakukan kegiatan budidaya ikan di tambak.

Kecamatan Manyak Payed memiliki 36 desa dan dari 36 desa tersebut terdapat 12 desa yang memiliki areal yang memiliki areal budidaya tambak, dengan luas tambak seluruhnya \pm 1.346 hektar. Dari luas tambak yang ada di Kecamatan Manyak Payed seluas 636 hektar areal tambak digunakan untuk budidaya bandeng

Tambak intensif merupakan perbaikan dari pola tambak non intensif, sistem intensif member kelangsungan produksi dan usaha 
dalam jangka waktu yang lebih lama dan pakan yang diandalkan tidak hanya pakan alam seperti tambak non intensif. Sedangkan tambak non intensif adalah pengolahan usaha budidaya perairan secara tradisional dengan padat tebar rendah dan hanya bisa dilakukan pada air tawar, partumbuhan ikan tergantung pada kondisi lingkungan dan sewaktu-waktu petani member makanan tambahan berupa sisa-sisa dapur pada ikan yang dibudidayakan.

Pendapatan usaha yang diperoleh dapat menjadi modal untuk pengembangan usaha tambak usaha ikan bandeng di masa mendatang. Mengingat kebutuhan keluarga yang terus meningkat setiap tahun harus dipacu dengan pengembangan usaha yang memadai agar pendapatan yang diperoleh usaha tambak ikan bandeng mampu mengimbangi akan kebutuhan yang terus meningkat setiap tahunnya. Perbedaan cara budidaya antara tambak ikan bandeng intensif dan non intensif diperkirakan akan memberikan perbedaan pendapatan kepada petani petambak.

Berdasarkan uraian pada latar belakang di atas penulis tertarik dan merasa penting untuk melakukan penelitian tentang analisis perbedaan penadapatan usaha budidaya ikan bandeng intensif dan non intensif di Kecamatan Manyak Payed Kabupaten Aceh Tamiang.

\section{Identifikasi Masalah}

"Apakah ada perbedaan yang nyata pendapatan usaha budidaya ikan bandeng (Chanos chanos) di Kecamatan Manyak Payed Kabupaten Aceh Tamiang?"

\section{Tujuan Penelitian}

"Untuk menganalisis perbedaan pendapatan usaha budidaya ikan bandeng (Chanos chanos) di Kecamatan Manyak Payed Kabupaten Aceh Tamiang".

\section{Hipotesis Penelitian}

"Ada perbedaan yang nyata pendapatan usaha budidaya ikan bandeng (Chanos chanos) secara intensif dan non intensif".

\section{METODOLOGI PENELITIAN Lokasi, Objek, Ruang Lingkup dan Waktu Penelitian}

Penelitian ini dilaksanakan di Kecamatan Mayak Payed Kabupaten Aceh Tamiang. Penentuan lokasi penelitian dilakukan dengan sengaja (purposive), dengan pertimbangan bahwa di Kecamatan Manyak Payed Kabupaten Aceh Tamiang terdapat usaha budidaya ikan bandeng secara intensif dan non intensif. Penelitian menggunakan metode survey. Metode survey adalah penelitian yang diadakan untuk memperoleh fakta dari gejala-gejala yang ada dan mencari keterangan-keterangan secara faktual tentang institusi sosial, ekonomi atau politik dari suatau daerah (Nazir, 2005:56). Objek penelitian ini adalah pengusaha tambak usaha budidaya ikan bandeng secara intensif dan non intensif di Kecamatan Manyak Payed. Ruang lingkup penelitian ini hanya mengkaji pendapatan pengusaha usaha budidaya ikan bandeng secara intensif dan non intensif.

\section{Penentuan Sampel Penelitian dan Pengumpulan Data Penentuan Sampel}

Kecamatan Manyak Payed terdiri dari 36 desa dan sebanyak 8 desa yang terdapat usaha budidaya ikan bandeng. Dari 8 desa tersebut secara sengaja (purposive sampling) diambil 3 desa untuk dijadikan sebagai desa sampel. Sugiyono (2010:122) menyatakan bahwa" Sampling Purposive" adalah teknik pengambilan sampel secara sengaja dengan pertimbangan tertentu". Desa-desa tersebut adalah Alue Sentang, Desa Meunasah Paya dan Desa Meurandeh, dengan pertimbangan bahwa desa-desa tersebut memiliki luas lahan yang lebih luas dibanding desa lainnya.

Sampel penelitian adalah pengusaha tambak budidaya ikan bandeng secara intensif dan non intensif yang berada di desa sampel di Kecamatan Manyak Payed. Menurut Nana (2005:5), "Sampel merupakan sebagian dari populasi yang paling tidak mempunyai cirriciri yang sama dengan poulasinya untuk mewakili populasi yang ada". Penentuan sampel dari pengusaha budidaya ikan bandeng intensif dilakukan dengan metode sensus (Full Sampling) atau semua populasi dijadikan sampel, dengan pertimbangan jumlah pengusaha budidaya ikan bandeng intensif jumlahnya sedikit. Penentuan sampel pengusaha budidaya ikan bandeng non intensif dari masing-masing desa sampel ditentukan secara simple random sampling (sampel acak 
sederhana). Metode sampel acak sederhana adalah teknik penentuan sampel secara acak tanpa mengenal sampel dengan cara diundi dengan mengikutkan semua populasi yang ada untuk dipilih secara acak. Besaran sampel sebanyak 5-30\% dari populasi dianggap layak untuk sebuah penelitian (Prasetyo dan Jannah, 2005:127). Untuk lebih jelas jumlah populasi dan sampel masing-masing desa sampel dapat dilihat pada tabel III-1 berikut:

Tabel III-1: Sampel Pengusaha Budidaya Ikan Bandeng Secara Intensif dan Non Intensif di Kecamatan Manyak Payed, 2016

\begin{tabular}{|c|c|c|c|c|c|}
\hline \multirow[t]{3}{*}{ No } & \multirow[t]{3}{*}{ Nama Desa } & \multicolumn{4}{|c|}{ Metode Budidaya Ikan Bandeng } \\
\hline & & \multicolumn{2}{|c|}{ Intensif (orang) } & \multicolumn{2}{|c|}{ Non Intensif (Orang) } \\
\hline & & Populasi & Sampel & Populasi & Sampel \\
\hline 1 & Alue Sentang & 7 & 7 & 152 & 8 \\
\hline 2 & Meunasah Paya & 9 & 9 & 113 & 6 \\
\hline 3 & Meurandeh & 5 & 5 & 324 & 16 \\
\hline & Jumlah & 21 & 21 & 502 & 30 \\
\hline
\end{tabular}

Sumber: Data Primer, 2016 (diolah)

Dari Tabel III-1 di atas dapat dilihat bahwa populasi pengusaha budidaya ikan bandeng intensif sebanyak 21 orang semuannya dijadikan sampel penelitian. Sedangan pengusaha budidaya ikan bandeng non intensif populasinya sebnayak 502 orang sebanyak 30 orang dijadikan sampel penelitian.

\section{Variabel dan Data yang Dianalisis}

Untuk menguji hipotesis yang telah diturunkan maka diperlukan beberapa variabel data, yaitu:
a. Penggunaan Tenaga kerja (HKP/Ha/Periode)
b. Biaya produksi (Rp/Ha/Periode)
c. Produksi $(\mathrm{Kg} / \mathrm{Ha} /$ Periode $)$
d. Harga jual ikan bandneg $(\mathrm{Rp} / \mathrm{Kg})$
e. Nilai Produksi/pendapatan kotor (Rp/Ha/Periode)
f. Pendapatan bersih/keuntungan (Rp/Ha/Periode)
g. Satu periode panen ikan bandeng yaitu 4 bulan

\section{Metode Analisis dan Pengujian Hipotesis Analisis Pendapatan Usaha Budidaya Ikan Bandeng}

Data yang diperoleh dari lapangan baik data primer maupun sekunder diolah dengan mentabulasikan dan kemudian dipindahkan ke dalam bentuk tabelaris seseuai kebutuhan analisis. Perhitungan pendapatan usaha dilakukan dengan menggunakan formulasi:

1) Analisis Biaya Produksi Usaha
Analisis biaya produksi dihitung dengan rumus:

$\mathrm{TC}=\mathrm{FC}+\mathrm{VC} \ldots \ldots \ldots \ldots . .($ Rahim

dan Retno, 2007:63)

Dimana;

TC : Total Cost (total biaya) ( $\mathrm{Rp} / \mathrm{Ha} /$ Periode)

FC : Fixed Cost (biaya tetap) (Rp/Ha/Periode)

VC : Variable Cost (biaya tidak tetap) (Rp/Ha/Periode)

2) Pendapatan Kotor Usaha

$\mathrm{TR}=\mathrm{Q} \times \mathrm{P} \ldots \ldots \ldots \ldots . . .($ Rahim dan

Retno, 2007:65)

Dimana:

$\mathrm{TR}=$ Pendapatan Kotor (Rp/Ha/Periode)

$\mathrm{Q}=$ Produksi Ikan Bandeng ( $\mathrm{Kg} / \mathrm{Ha} /$ Periode)

$\mathrm{P} \quad=$ Harga Jual Ikan Bandeng $(\mathrm{Rp} / \mathrm{Kg})$

3) Pendapatan Bersih Usaha

$\mathrm{Pd}=\mathrm{TR}-\mathrm{TC} \ldots \ldots \ldots \ldots \ldots . . .($ Rahim

dan Retno, 2007:68)

Dimana:

$\mathrm{Pd}=$ Pendapatan Bersih (Rp/Ha/Periode)

$\mathrm{TR}=$ Pendapatan Kotor ( $\mathrm{Rp} / \mathrm{Ha} /$ Periode)

$\mathrm{TC}=$ Total Biaya $(\mathrm{Rp} / \mathrm{Ha} /$ Periode $)$

Analisis Perbedaan Pendapatan Usaha Budidaya Ikan Bandeng Intensif dan Non Intensif

Untuk menguji perbedaan pendapatan usaha budidaya ikan bandeng intensif dan non 
intensif, dilakukan dengan uji statistik uji beda rata-rata (Sugiono, 2010:119). Formulasinya sebagai berikut :

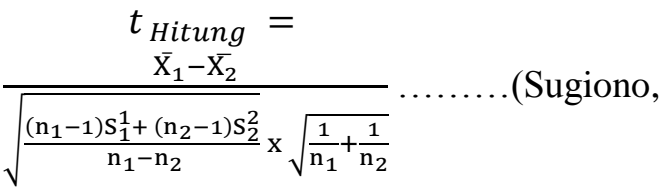

2010:122)

Dimana:

$\overline{\mathrm{X}}_{1}$ dan $\overline{\mathrm{X}}_{2} \quad=$ Rata-rata pendapatan usaha budidaya ikan bandeng intensif dan non intensif

$S_{1}^{2}$ dan $S_{2}^{2}=$ Rata-rata varian pendapatan bersih usaha budidaya ikan bandeng

intensif dan non intensif

$n_{1}$ dan $n_{2} \quad=$ Jumlah sampel pengusaha usaha budidaya ikan bandeng intensif dan

non intensif

Pengujian hipotesis sebagai berikut:

- Ha: yaitu ada perbedaan signifikan pendapatan usaha budidaya ikan bandeng intensif dan non intensif

- Ha: yaitu ada perbedaan signifikan pendapatan usaha budidaya ikan bandeng intensif dan non intensif

Kriteria Uji :

- $\quad$ Terima Ha dan tolak Ho apabila t-hitung $>$ t-tabel, $\mathrm{db}=\mathrm{n}-1, \alpha=0.05$

- Tolak Ha dan terima Ho apabila t-hitung $<\mathrm{t}$-tabel, $\mathrm{db}=\mathrm{n}-1, \alpha=0.05$

Penggunaan alpha sebesar 5\% dalam uji statistik t-hitung sesuai dengan kebutuhan peneliti yang juga didasarkan pada pernyataan Usman, dkk (2008:85), bahwa dalam penelitian sosial, besarnya alpha (tingkat kesalahan) yang digunakan dapat bernilai $1 \%$ atau 5\% atau tingkat keyakinan 95\% dan 99\%.

\section{HASIL PENELITIAN DAN PEMBAHASAN}

Karakteristik Petani Sampel

Karakteristik pengusaha dalam penelitian ini meliputi luas lahan, umur, pendidikan, pengalaman dalam berusaha tambak ikan bandeng dan besar tanggungan keluarga. Rini (2005:26), "pengertian karakteristik individu adalah bagian dari pribadi dan melekat pada diri seseorang. Karakteristik ini mendasari tingkah laku seseorang dalam situasi kerja maupun situasi yang lainnya". Karakteristik akan mempengaruhi pengusaha dalam mengelola usaha selama proses produksi berlangsung. Pengusaha dalam menjalankan usahanya memiliki fungsi ganda yaitu disamping sebagai manager usaha juga sebagai buruh (juru tani).

Karakteristik pengusaha budidaya ikan bandeng non intensif di Kecamatan Manyak Payed dimana rata-rata umur pengusaha adalah 47,27 Periode merupakan umur yang produktif dalam mengusahakan usaha bandeng. Tingkat pendidikan rata-rata adalah 9,74 Periode dengan rata-rata pengalaman berusahatani 10,55 Periode dan jumlah tanggungan keluarga rata-rata 5 orang.

Karakteristik pengusaha budidaya ikan bandeng intensif di Kecamatan Manyak Payed dimana

rata-rata umur pengusaha adalah 42,24 Periode merupakan umur yang produktif dalam mengusahakan usaha bandeng. Tingkat pendidikan rata-rata adalah 11,71 Periode dengan rata-rata pengalaman berusahatani 9,10 Periode dan jumlah tanggungan keluarga ratarata 3 orang.

\section{Penggunaan Tenaga Kerja}

Tenaga kerja merupakan salah satu faktor produksi yang sangat penting artinya dalam kegiatan memproduksi dan menjalankan usaha budidaya ikan bandeng, baik itu usaha budidaya ikan bandeng non intensif dan yang intensif. Penggunaan tenaga kerja harus dilakukan seefisien dan seefektif mungkin karena untuk menghindari membengkaknya biaya produksi. Tenaga kerja (TK) yang digunakan pada usaha budidaya ikan bandeng non intensif terdiri dari tenaga kerja dalam keluarga (DK) dan luar keluarga (LK) yang terdiri dari tenaga kerja pria, wanita dan anak-anak.

Penggunaan tenaga kerja pada usaha budidaya bandeng meliputi fase kegiatan persiapan lahan tambak, penaburan benih, pemeliharaan tambak, pemberian pakan dan pemanenan/pengangkutan. Dalam menghitung besarnya pencurahan tenaga kerja yang diserap untuk setiap fase kegiatan, seluruhnya dikonversikan ke dalam Hari Kerja Pria (HKP). Rata-rata penggunaan tenaga kerja usaha budidaya ikan bandeng non intensif dimana rata-rata pengunaan tenaga kerja usaha budidaya ikan bandeng non intensif yaitu sebesar 34,07 HKP/Periode dengan rincian 21,07 $\mathrm{HKP} /$ Periode tenaga kerja dalam 
keluarga dan 13,04 HKP/Periode tenaga kerja luar keluarga.

Rata-rata penggunaan tenaga kerja usaha budidaya ikan bandeng intensif di Kecamatan Manyak Payed dimana rata-rata penggunaan tenaga kerja usaha budidaya ikan bandeng intensif yaitu sebesar 85,25 HKP/UT/Periode dengan rincian 45,71 HKP tenaga kerja dalam keluarga dan 39,54 HKP tenaga kerja luar keluarga.

\section{Biaya Produksi}

Pengertian biaya produksi dalam penelitian ini adalah semua biaya yang Tabel V-5. Rata-Rata Biaya Produksi Usaha Budidaya Ikan Bandeng Non Intensif di Kecamatan Manyak Payed, 2016

\begin{tabular}{|l|l|c|c|c|}
\hline No & \multicolumn{1}{|c|}{ Desa } & $\begin{array}{c}\text { Biaya Tetap } \\
\text { (Rp/Periode) }\end{array}$ & $\begin{array}{c}\text { Biaya Variabel } \\
\text { (Rp/Periode) }\end{array}$ & $\begin{array}{c}\text { Total Biaya } \\
\text { (Rp/Periode) }\end{array}$ \\
\hline 1 & Alue Sentang & $951.872,22$ & $2.721 .250,00$ & $3.673 .122,22$ \\
2 & Meunasah Paya & $1.200 .389,28$ & $3.393 .541,67$ & $4.593 .930,95$ \\
3 & Meurandeh & $957.623,26$ & $2.756 .250,00$ & $3.713 .873,26$ \\
\hline \multicolumn{2}{r|}{ Rata-Rata } & $1.004 .642,86$ & $2.874 .375,00$ & $3.879 .017,86$ \\
\hline
\end{tabular}

Sumber : Data primer diolah, 2017

Tabel V-5 di atas dapat dilihat rata-rata biaya produksi usaha budidaya ikan bandeng non intensif di Kecamatan Manyak Payed yaitu sebesar Rp. 3.879.017,86,- perUT/Periode dengan rincian biaya tetap sebesar $\mathrm{Rp}$. diperlukan untuk memperlancar kegiatan usaha budidaya ikan bandeng. Biaya tetap (Fixed Cost) dalam penelitian ini adalah sewa lahan, biaya penyusutan dan pajak bumi dan bangunan (PBB). Sedangkan biaya variabel adalah biaya yang dikeluarkan untuk membeli benih, pakan, pupuk, obat-obatan dan membayar upah tenaga kerja.

Rata-rata penggunaan biaya produksi usaha budidaya ikan bandeng non intensif di Kecamatan Manyak Payed dapat dilihat pada tabel V-5 berikut ini:
1.004.642,86,- perUT/Periode dan biaya variabel sebesar Rp. 2.874.375 perUT/Periode.

Rata-rata penggunaan biaya produksi pada usaha budidaya ikan bandeng intensif di Kecamatan Manyak Payed dapat dilihat pada tabel V-6 berikut ini :
Tabel V-6. Rata-Rata Biaya Produksi Usaha Budidaya Ikan Bandeng Intensif di Kecamatan Manyak Payed, 2016

\begin{tabular}{|l|l|c|c|c|}
\hline No & \multicolumn{1}{|c|}{ Desa } & $\begin{array}{c}\text { Biaya Tetap } \\
\text { (Rp/Periode) }\end{array}$ & $\begin{array}{c}\text { Biaya Variabel } \\
\text { (Rp/Periode) }\end{array}$ & $\begin{array}{c}\text { Total Biaya } \\
\text { (R/Periode) }\end{array}$ \\
\hline 1 & Alue Sentang & $1.452 .851,85$ & $6.077 .916,67$ & $7.530 .768,52$ \\
2 & Meunasah Paya & $1.387 .771,60$ & $5.615 .277,78$ & $7.003 .049,38$ \\
3 & Meurandeh & $1.576 .477,78$ & $6.766 .250,00$ & $8.342 .727,78$ \\
\hline & Rata-Rata & $1.460 .282,01$ & $6.076 .309,52$ & $7.536 .591,53$ \\
\hline
\end{tabular}

Sumber : Data primer diolah, 2017

Tabel V-6 di atas dapat dilihat bahwa rata-rata biaya produksi usaha budidaya ikan bandeng intensif di Kecamatan Manyak Payed yaitu sebesar Rp. 7.536.591,53perUT/Periode dengan rincian biaya tetap sebesar Rp. 1.460.282,01,- perUT/Periode dan biaya variabel sebesar Rp. 6.076.309,52 perUT/Periode.

Dengan mengacu pada Tabel V-5 dan Tabel V-6 maka terdapat perbedaan rata-rata biaya produksi usaha budidaya ikan bandeng non intensif dan intensif sebesar $R p$.
3.657.573,67- per UT/Periode. Perbedaan biaya produksi tersebut disebabkan pada budidaya ikan bandeng intensif lebih banyak menabur benih ikan bandeng perhektarnya sehingga biaya membeli benih lebih besar, selanjutnya biaya tenaga kerja juga lebih besar, karena intensif pakan diberikan teratur setiap hari sehingga biaya pakan menjadi lebih besar. Begitu juga biaya pupuk, pestisida dan lainnya menjadi lebih besar. Tetapi biaya yang lebih besar akan tertutupi dangan produksi yang tinggi dimana jumlah ikan yang dipanen 
lebih banyak dan bobot perekor menjadi lebih berat karena diberi pakan secara teratur sehingga pertumbuhannya menjadi lebih cepat.

\section{Produksi Ikan Bandeng}

Produksi adalah hasil produksi yang diperoleh pengusaha dari usaha budidaya ikan bandeng dalam bentuk ikan bandeng siap panen. Produksi ikan bandeng biasanya dapat dipanen pada saat umur ikan selama 6 bulan. Rata-rata produksi usaha budidaya ikan bandeng non intensif di Kecamatan Manyak Payed dapat dilihat pada tabel V-7 berikut ini.

Tabel V-7. Rata-Rata Produksi Pada Usaha Budidaya Ikan Bandeng Non Intensif di Kecamatan Manyak Payed, 2016

\begin{tabular}{|l|l|c|c|}
\hline \multirow{2}{*}{ No } & \multirow{2}{*}{ Desa } & Per UT (Kg/UT/Periode) & Per UT (Kg/Ha/Periode) \\
\cline { 2 - 4 } 2 & Alue Sentang & 467.50 & 352.83 \\
2 & Meunasah Paya & 567.08 & 349.87 \\
3 & Meurandeh & 461.88 & 351.90 \\
\hline \multicolumn{2}{|c|}{ Rata-Rata } & 484.42 & 351.66 \\
\hline
\end{tabular}

Sumber : Data primer diolah, 2017

Tabel V-7 di atas dapat dilihat bahwa rata-rata produksi ikan bandeng usaha budidaya non intensif sebesar 484,42
$\mathrm{Kg} / \mathrm{UT} /$ Periode dan 351,66 $\mathrm{Kg} / \mathrm{Ha} /$ Periode. Rata-rata produksi usaha budidaya ikan bandeng intensif di Kecamatan Manyak Payed dapat dilihat pada tabel V-8 berikut ini.

Tabel IV-8. Rata-Rata Produksi Pada Usaha Budidaya Ikan Bandeng Intensif di Kecamatan Manyak Payed, 2016

\begin{tabular}{|c|c|c|c|}
\hline \multirow[b]{2}{*}{ No } & \multirow[b]{2}{*}{ Desa } & \multicolumn{2}{|c|}{ Produksi } \\
\hline & & Per UT (Kg/UT/Periode) & Per UT (Kg/Ha/Periode) \\
\hline 1 & Alue Sentang & 795.67 & 524.62 \\
\hline 2 & Meunasah Paya & 660.00 & 516.52 \\
\hline 3 & Meurandeh & 763.00 & 526.21 \\
\hline . & Rata-Rata & 728.19 & 521.91 \\
\hline
\end{tabular}

Sumber : Data primer diolah, 2017

Tabel V-8 di atas dapat dilihat bahwa rata-rata produksi usaha budidaya ikan bandeng intensif yaitu sebesar 728,19 $\mathrm{Kg} / \mathrm{UT} /$ Periode dan $521,91 \mathrm{Kg} / \mathrm{Ha} /$ Periode. Dengan mengacu pada Tabel V-7 dan Tabel V-8 maka terdapat perbedaan rata-rata produksi usaha budidaya ikan bandeng non intensif dan intensif di Kecamatan Manyak Payed sebesar 170,25 $\mathrm{Kg} / \mathrm{Ha} /$ Periode $(32,62 \%)$. Selisih produksi sebesar 170,25 Kg/Ha/Periode adalah sebuah perbedaan yang besar sehingga pengusaha budidaya ikan bandeng intensif memperoleh pendapatan jauh lebih besar dibandingkan dengan pengusaha ikan bandeng non intensif dikarenakan perbedaan produksi yang cukup besar.
Nilai Produksi (Pendapatan Kotor) Usaha Budidaya Ikan Bandeng

Nilai produksi (pendapatan kotor) adalah total perkalian produksi dan harga produksi yang diterima pengusaha dari usaha budidaya ikan bandeng. Besarnya nilai produksi sangat ditentukan oleh harga yang berlaku saat pengusaha menjual hasil produksinya. Pada saat penelitian ini dilakukan harga ikan bandeng yang diterima pengusaha budidaya ikan bandeng di Kecamatan Manyak Payed adalah Rp. 20.000,- per kilogram untuk ikan bandeng hasil budidaya non intensif dan Rp. 22.000,per kilogram untuk ikan bandeng hasil budidaya intensif. Perbedaan harga jual ini dikatakan oleh pedagang pengumpul bahwa kualitas rasa ikan bandeng hasil budidaya intensif lebih baik. Rata-rata nilai produksi usaha budidaya ikan bandeng non intensif di 
Tabel V-9. Rata-Rata Nilai Produksi Pada Usaha Budidaya Ikan Bandeng Non Intensif di Kecamatan Manyak Payed, 2016

\begin{tabular}{|l|l|r|r|}
\hline \multirow{2}{*}{ No } & \multirow{2}{*}{ Kecamatan } & \multicolumn{2}{|c|}{ Pendapatan Kotor (Nilai Produksi) } \\
\cline { 2 - 4 } 1 & Alue Sentang & $9.350 .000,00$ & Per Ha (Rp/Ha/Periode) \\
2 & Meunasah Paya & $11.341 .666,67$ & $7.056 .603,77$ \\
3 & Meurandeh & $9.237 .500,00$ & $6.997 .429,31$ \\
\hline \multicolumn{2}{|c|}{ Rata-Rata } & $9.688 .333,33$ & $7.038 .095,24$ \\
\hline
\end{tabular}

Sumber : Data primer diolah, 2017

Tabel V-9 di atas dapat dilihat bahwa rata-rata nilai produksi usaha budidaya ikan bandeng non intensif di Kecamatan Manyak Payed yaitu sebesar Rp. 9.688.333,33,-
/Usaha/Periode dan Rp. 7.033.272,84,$/ \mathrm{Ha} /$ Periode.

Rata-rata nilai produksi usaha budidaya ikan bandeng intensif di Kecamatan Manyak Payed dapat dilihat pada tabel V-10 berikut ini.

Tabel V-10. Rata-Rata Nilai Produksi Pada Usaha Budidaya Ikan Bandeng Intensif di Kecamatan Manyak Payed, 2016

\begin{tabular}{|l|l|c|c|}
\hline \multirow{2}{*}{ No } & \multirow{2}{*}{ Kecamatan } & \multicolumn{2}{|c|}{ Pendapatan Kotor (Nilai Produksi) } \\
\cline { 3 - 4 } 1 & Alue Sentang & $17.504 .666,67$ & Per UT (Rp/Ha/Periode) \\
2 & Meunasah Paya & $14.520 .000,00$ & $11.541 .538,46$ \\
3 & Meurandeh & $16.786 .000,00$ & $11.363 .478,26$ \\
\hline \multicolumn{2}{|c|}{ Rata-Rata } & $16.020 .190,48$ & $11.576 .551,72$ \\
\hline
\end{tabular}

Sumber : Data primer diolah, 2017

Tabel IV-11 di atas dapat dilihat bahwa ratarata nilai produksi (pendapatan kotor) usaha budidaya ikan bandeng intensif di Kecamatan Manyak Payed yaitu sebesar Rp. 16.020.190,48,-/Usaha dan Rp. 11.482.047,78,-/Ha/Periode.

Mengacu pada Tabel V-9 dan V-10, terdapat perbedaan rata-rata nilai produksi usaha budidaya ikan bandeng non intensif dan intensif sebesar Rp. 4.448.774,94 per $\mathrm{Ha} /$ Periode $(38,74 \%)$. Perbedaan pendapatan kotor antara usaha budidaya ikan bandeng non intensif dan intensif sebesar 38,74\% merupakan perbedaan yang besar yang disebabkan perbedaan produksi perhektar dan harga jual ikan bandeng perkilogram.

\section{Pendapatan Bersih Usaha Budidaya Ikan Bandeng}

Pendapatan bersih yaitu selisih antara nilai produksi dengan total biaya produksi. Rata-rata pendapatan bersih usaha budidaya ikan bandeng non intensif di Kecamatan Manyak Payed dapat dilihat pada tabel V-11 berikut ini.

Tabel V-11. Rata-Rata Pendapatan Bersih Usaha Budidaya Ikan Bandeng Non Intensif di Kecamatan Manyak Payed, 2016

\begin{tabular}{|l|l|r|r|}
\hline \multirow{2}{*}{ No } & \multirow{2}{*}{ Desa } & \multicolumn{2}{|c|}{ Pendapatan Bersih } \\
\cline { 3 - 4 } 1 & Alue Sentang & $5.676 .877,78$ & Per HT (Rp/UT/Periode) \\
2 & Meunasah Paya & $6.747 .735,72$ & $4.242 .012,59$ \\
3 & Meurandeh & $5.523 .626,74$ & $4.835 .993,42$ \\
\hline & Rata-Rata & $5.809 .315,48$ & $4.201 .067,19$ \\
\hline
\end{tabular}

Sumber : Data primer diolah, 2017 
Tabel V-11 di atas dapat dilihat bahwa ratarata pendapatan bersih usaha budidaya ikan bandeng non intensif di Kecamatan Manyak Payed yaitu sebesar Rp. 5.809.315,48 perUT/Periode dan Rp. 4.338.971,21 per $\mathrm{Ha} /$ Peripode.
Rata-rata pendapatan bersih usaha budidaya ikan bandeng intensif di Kecamatan Manyak Payed dapat dilihat pada tabel V-12 berikut.

Tabel V-12. Rata-Rata Pendapatan Bersih Usaha Budidaya Ikan Bandeng di Kecamatan Manyak Payed, 2016

\begin{tabular}{|l|l|r|r|}
\hline \multirow{2}{*}{ No } & \multirow{2}{*}{ Desa } & \multicolumn{2}{|c|}{ Pendapatan Bersih } \\
\cline { 2 - 4 } 2 & Alue Sentang & Per UT (Rp/UT/Periode) & Per Ha (Rp/Ha/Periode) \\
2 & Meunasah Paya & $9.973 .898,15$ & $6.567 .076,96$ \\
3 & Meurandeh & $7.516 .950,62$ & $5.843 .584,88$ \\
& Rata-Rata & $8.443 .272,22$ & $5.815 .597,20$ \\
\hline
\end{tabular}

Sumber : Data primer diolah, 2017

Tabel V-12 di atas dapat dilihat bahwa ratarata pendapatan bersih usaha budidaya ikan bandeng intensif di Kecamatan Manyak Payed yaitu sebesar Rp. 8.483.598,94- per UT/Periode dan Rp. 6.042.300,43,- per Ha/Periode.

Dengan mengacu pada Tabel V-11 dan Tabel V-12 maka terdapat perbedaan ratarata pendapatan bersih usaha budidaya ikan bandeng non intensif dan intensif di Kecamatan Manyak Payed sebesar Rp. 1.703.329,22 per Ha/Periode.

\section{Analisis Perbedaan Pendapatan Usaha Budidaya Ikan Bandeng Non Intensif dan Intensif di Kecamatan Manyak Payed.}

Berdasarkan hasil penelitian diperoleh data ada perbedaan pendapatan bersih antara usaha budidaya ikan bandeng non intensif dan intensif di Kecamatan Manyak Payed, dimana pendapatan bersih usaha budiadaya ikan bandeng intensif lebih tinggi dibandingkan dengan pendapatan bersih usaha budidaya ikan bandeng non intensif. Untuk lebih meyakinkan apakah perbedaan tersebut nyata atau tidak nyata secara statistik, maka dilakukan pengujian statistik uji " $t$ ". Dari hasil perhitungan tersebut diperoleh $t_{\text {cari }}=13,101$ sedangkan $t_{\text {tabel }}$ pada tingkat keyakinan $95 \%$ $(\alpha=0.05)$ sebesar 1,665 dan pada tingkat keyakinan $99 \%(\alpha=0.01)$ sebesar 2,405. Ini berarti $t_{\text {cari }}>t_{\text {tabel }}$ baik pada tingkat keyakinan 95\% maupun 99\%. Dengan demikian dapat disimpulkan terima Ha dan tolak Ho. Artinya ada perbedaan yang sangat nyata antara pendapatan bersih usaha budidaya ikan bandeng non intensif dan intensif.

AGRISAMUDRA, Jurnal Penelitian Vol. 4 No.2 Julii - Desember 2017
Hasil penelitian menunjukkan bahwa ada perbedaan yang sangat nyata antara pendapatan usaha budidaya ikan bandeng non intensif dan intensif. Hal ini disebabkan oleh karena perbedaan produksi antara keduanya yang menyebabkan perbedaan penerimaan dan pada akhirnya terjadi perbedaan pendapatan bersih antara keduanya. Perbedaan pendapatan juga terjadi karena perbedaan pada biaya produksi antara usaha budidaya ikan bandeng non intensif dan intensif, sehingga terjadi selisih antara penerimaan dan biaya produksi lebih besar pada usaha budidaya ikan bandeng intensif dibandingkan dengan non intensif.

\section{KESIMPULAN DAN SARAN Kesimpulan}

1. Rata-rata pendapatan bersih usaha budidaya ikan bandeng non intensif di Kecamatan Manyak Payed yaitu sebesar Rp. 5.809.315,48 perUT/Periode dan Rp. 4.338.971,21 per $\mathrm{Ha} /$ Periode dan rata-rata pendapatan bersih usaha budidaya ikan bandeng intensif yaitu sebesar Rp. 8.483.598,94- per UT/Periode dan Rp. 6.042.300,43,- per Ha/Periode.

2. Dari hasil perhitungan tersebut diperoleh $t_{\text {cari }}=13,101$ sedangkan $t$ tabel pada tingkat keyakinan 95\% $(\alpha=0.05)$ sebesar 1,665 dan pada tingkat keyakinan $99 \% \quad(\alpha=0.01)$ sebesar 2,405. Ini berarti $t_{\text {cari }}>t_{\text {tabel }}$ baik pada tingkat keyakinan 95\% maupun $99 \%$. Dengan demikian dapat disimpulkan terima Ha dan tolak Ho. Artinya ada perbedaan yang sangat 
nyata antara pendapatan bersih usaha budidaya ikan bandeng non intensif dan intensif.

\section{Saran}

1. Perlu kajian yang mendalam mengenai faktor-faktor penyebab masih adanya budidaya ikan bandeng non intensif, dimana berdasarkan hasil penelitian ini pendapatannya jauh lebih rendah dibandingkan yang intensif.

2. Jika diketahaui faktor-faktor penyebab pengusaha masih menjalankan budidaya ikan bandeng non intensif maka perlu dipikirkan alternatif penyelesaian masalah yang pada akhirnya ketika pengusaha beralih menjadi pengusaha budidaya ikan bandeng intensif akan meningkatkan pendapatan pengusaha.

Disarankan kepada pengusaha budidaya ikan bandeng non intensif untuk beralih menjadi pengusaha budidaya ikan bandeng intensif karena sudah terbukti mendapatkan pendapatan yang lebih tinggi.

\section{DAFTAR PUSTAKA}

Ahira, anne, 2012. Penggunaan Pupuk Urea Pada Iklim Tropis. Kanisius, Jakarta

Anonimous. 2015, Potensi Wilayah Kecamatan Kejuruan Muda, BPP Kejuruan Muda

Dany. 1996. Pengantar Ekonomi Pertanian. Bumi Aksara, Jakarta.

Dalimartha, S. 2008. Atlas Tumbuhan Obat Indonesia Jilid 3. Jakarta: Perpustakaan Nasional RI

Daniel. (2001) Pemasaran. (edisi pertama). Jakarta: Salemba Empat.

Hermanto Fadholi. 2001. Ilmu Usahatani. Penenbar Swadaya: Jakarta.

Kalie. M. B. 1994. Budiadaya Rambutan Varietas Unggul. Kanisius. Jakarta.

Mubyarto, 1994, Pengantar Ekonomi Pertanian, LP3ES, Jakarta

Mubyarto, 2002, Pengantar Ekonomi Pertanian, LP3ES, Jakarta

Nazir, Moh, 2005, Metode Penelitian, Cetakan Keenam, Ghalia Indonesia, Jakarta

Rahim dan Diah Retno, 2007, Ekonomika Pertanian, Penebar Swadaya, Jakarta

Rasahan C.A. 2002. Kontribusi Sektor Pertanian Menuju Struktur
Pendapatan Berimbang di Perdesaan.

Dalam : Perkembangan Struktur

Produksi, Ketenagakerjaan, dan

Pendapatan Rumahtangga Pedesan.

Prosiding. Pusat Penelitian Agro

Ekonomi, Bogor. Hlm 229-237.

Simatupang, 2003. Studi Keragaman Rambutan di Sumatera Utara Sebagai Salah Satu Pendukung Pembangunan Pertanian yang Berkelanjutan, PascaSarjana USU, Medan Sumatera Utara..

Soekartawi. 2002. Ilmu Usahatani dan Peneitian untuk Pengembangan Petani Kecil. Universitas Indonesia Press, Jakarta.

Sunarjono, 2000. Teori ekonomi produksi. Raja Grafindo Persada. Jakarta.

Prawirokusumo, S. 2000. Ilmu Usaha Tani, BPIE Yogyakarta.

Prasetyo dan Miftahul Jannah. 2005. Metode Penelitian Kuantitatif. PT. Raja Grafindo Persada. Jakarta

Yandianto, 2003. Bercocok Tanam Padi. M2S. Bandung

Yunus, Y. 2004. Tanah dan Pengolahannya, Alphabeta, Bandung 